\title{
Economic value of ecosystem services in Protected Landscape Areas in the Czech Republic
}

\author{
*Jan Daněk ${ }^{1}$, David Vačkářr ${ }^{1}$, Eliška Krkoška Lorencová ${ }^{1}$ \\ 1) Global Change Research Institute, Czech Academy of Sciences, Bëlidla 986/4a, 60300 Brno, Czech Republic, \\ Department of Human Dimensions of Global Change, V Jirchárích 149/6, 11000 Praha 1 email: danek.j@czech- \\ globe.cz
}

Abstract: Daněk J., Vačkář D., Krkoška Lorencová E. 2017: Value of ecosystem services in Protected Landscape Areas in the Czech Republic - Beskydy, 10 (1, 2): 99-112

This study aims to explore spatially explicit economic values of ecosystem services provided by ecosystems and habitats in 25 Protected Landscape Areas (PLAs) in the Czech Republic, with a more detailed overview of three selected PLAs (Beskids Mountains, Český les Mountains and Odra River Basin). In the methodology, combination of the Consolidated Layer of Ecosystems of the Czech Republic (CLES) and the EKOSERV database allowed us to utilize the ecosystem and economic valuation data in a specific geographic context using a GIS-based approach. The total value of ecosystem services in all 25 PLAs reached $€ 51$ billion/year, with the surface area significantly influencing the total average value of a particular PLA. When transformed to value per unit area, the values varied from $€ 1.2$ to $€ 6.5$ million $/ \mathrm{km}^{2} /$ year. The results suggest a dominant role of forest ecosystems in the composition of the economic value provided by ecosystem services in the PLAs. Economic valuation of benefits provided by protected areas can help to realize the social importance of these sites and to support policy and decisionmaking processes.

Keywords: ecosystem services, economic valuation, Protected Landscape Areas, forest ecosystems

\section{Introduction}

Protected areas and their ecosystems provide people and society with vital ecosystem services. However, the ecosystems might be subject to degradation, which has been mentioned on numerous occasions both in policy and scientific discourses (Costanza et al. 2017; Steffen et al. 2011; MA 2005). Some authors suggest the process can be influenced by expressing, unhiding or making visible the multiple values and benefits provided by nature to people (Frélichová et al. 2014; Daily et al. 2009).

The concept of ecosystem services has successfully made its way into an increasingly popular research topic over the last decades
(Kull et al. 2015). It has also become an important framework describing values of nature, often in monetary terms (Costanza et al. 2017; Bennett et al. 2015). Nonetheless, it is arguably an anthropocentric concept, and as such it has been the butt of criticism as well as counter-arguments (Schröter et al. 2014; McCauley 2006). However, it cannot be denied that this concept offers us a unique framework, allowing us to assess and communicate often invisible or overlooked values and benefits (but also some disservices ${ }^{1}$, see Lyytimäki 2015) provided by nature to society or individuals. Various outcomes of ecosystem service research provide support

1 "Ecosystem disservices (EDS) are functions or properties of ecosystems that cause effects that are perceived as harmful, unpleasant or unwanted. Examples of EDS include pest damages to agriculture, pollen causing allergic reactions or fear related to night-time urban parks." (Lyytimäki 2015) 
tools for policy and decision-making processes, such as ecosystem assessments, economic valuation, mapping of ecosystems and ecosystem services.

In the European context, few countries have completed a national ecosystem assessment in its broad sense (Schröter et al. 2016). However, some countries are conducting related activities or have at least done some mapping of ecosystems or undertaken a pilot study on ecosystem assessment (MAES 2016). In the Czech Republic, two studies on ecosystem services assessment have been carried out at national level (Frélichová et al. 2014; Hönigová et al. 2012). Both studies included estimations of economic value of ecosystem services. The prime focus of the study by Frélichová et al. (2014) is on assessment of six ecosystem types (aquatic ecosystems, agricultural ecosystems, forests, grasslands, urban areas, wetlands) and 17 ecosystem services across the territory of the country. The study by Hönigová et al. (2012) focuses on a single ecosystem type - grasslands.

Protected areas have been traditionally declared to conserve natural values, based on the distributions of threatened and important species and habitats or features of geomorphological significance. However, it is widely recognized that protected areas are contributing to the maintenance of vital ecosystem processes which translate into the ecosystem services value for society (Durán et al. 2013). Despite the recent efforts in ecosystem services valuation, there are few studies on the economic value of ecosystem services in specially protected areas (Whitham et al. 2014; Ingraham \& Foster 2008). Exploring, assessing and showing the economic value of ecosystems and the benefits they provide to society or individuals is one of the ways to express and quantify the extent to which nature contributes (directly or indirectly) to human well-being (MA 2005). Valuation of ecosystem services can be a useful starting point to highlight benefits provided by ecosystems in order to inform environmental management and related policies for nature protection and local development.

\section{Research objectives}

This study draws on the results from previous research by Frélichová et al. (2014), which provide an integrated assessment of ecosystem services in the Czech Republic. While having a different research subject, protected areas, it further expands the usability of previously gathered data and databases. This paper applies the ecosystem assessment data in a new, more detailed context in order to expand the body of knowledge about ecosystem services in protected areas and their societal benefits, expressed as an estimation of economic value. Generally, the goal is to explore spatially explicit economic values provided by ecosystems and habitats in large-scale protected areas.

The primary task was to identify the factors regarding ecosystem and habitat structure which play a major role in estimating the economic value of Protected Landscape Areas (PLAs) in the Czech Republic. Ecosystem types and values were extracted using a previously developed methodology and valuation database by Frélichová et al. (2014) and applied in a new context. Selected PLAs were further analysed in order to answer the question whether the highest value of a single ecosystem relates to ecosystems with the largest surface area and which habitats contribute the most to the overall value of a particular PLA.

\section{Material and Methods}

\section{Study sites}

According to Act No. 114/1992 Coll. on Nature and Landscape Protection, there are six types of Specially Protected Areas in the Czech Republic - two large scale categories - National Park and Protected Landscape Area; and four small scale categories - National Nature Reserve, Nature Reserve, National Nature Monument, and Nature Monument. This study examines specifically PLAs which Act No. 114/1992 Coll. defines as extensive areas with a harmonic landscape, a specific relief, a significant share of natural ecosystems of forest and natural grasslands, and an abundance of woody species. The PLAs might also include some historical settlement relics. The management of the PLAs must be carried out according to specific 3-4 zones of protection in order to preserve and improve the natural state of the PLAs and to create and protect optimal ecological functions in these areas. Recreational use of the PLAs is allowed only if it does not damage their natural values.

Currently, there are 26 PLAs in the territory of the Czech Republic, covering $14.39 \%$ of the country's surface area. This study includes 25 
PLAs, because the latest PLA, Brdy Highlands, was created only recently (in 2016) and was not included in the CLES at the time of the research. The total area of the 25 PLAs covered in this study is $13.78 \%$ of the country's surface area. Based on the results, three PLAs were selected for a further analysis.

\section{Spatial data}

Since ecosystem services are inherently linked to and depended on ecosystems, the first essential step is to identify relevant ecosystems, habitats or land-use, in order to assign to them relevant ecosystem services and value them. The source of the spatial ecosystem data for the PLAs was from the Consolidated Layer of Ecosystems of the Czech Republic (CLES), which has been made by CzechGlobe together with Nature Conservation Agency of the Czech Republic in 2012. The CLES utilizes Habitat Mapping Layer (originally made to identify the Natura 2000 sites), Corine Land Cover (2006), Urban Atlas, ZABAGED geographic data, and other specific data for water bodies (DIBAVOD) (Frélichová et al. 2014). The CLES consists of 41 habitat/land-use categories, hierarchically classified at four levels (Table 1 in the supplementary material). The highest level comprises seven ecosystem types: aquatic ecosystems, agricultural ecosystems, bare land, forests, grasslands, urban areas, and wetlands. For example, the lowest level of Forests ecosystem type contains 13 habitat types: e.g. intensive mixed forests, alluvial forests, spruce forests or natural shrub vegetation. Fig. 1 provides an overview of 38 relevant habitat/ land-use categories presented in three selected PLAs.

\section{Classification of ecosystem services}

Ecosystem services are classified into three basic categories, regulating, provisioning and cultural, in line with the most globally used classifications - MA (2005), TEEB (2013), and CICES v4.3 (Haines-Young \& Potschin 2013). The fourth category of supporting services is not included as it might cause double counting errors (Frélichová et al. 2014; Bateman et al. 2011). Based on the existing ecosystems and environmental conditions in the Czech Republic, a selection of 18 relevant services was made (Frélichová et al. 2014). The complete list with the relevant ecosystems, where the economic valuation was applied, is presented in Tab. 1.

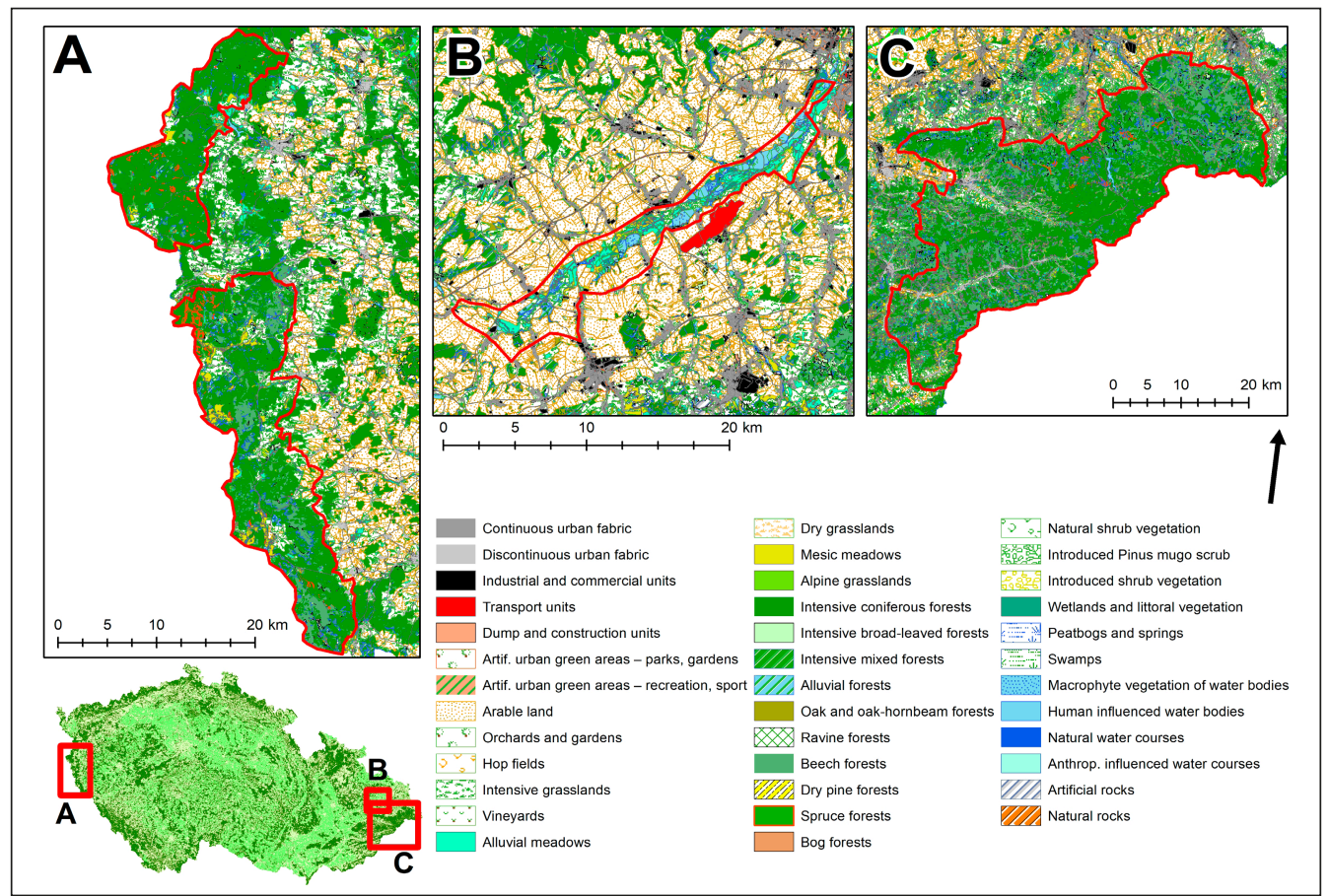

Fig. 1: 38 relevant habitat/land-use categories by CLES presented in three selected PLAs (A - Český les Mountains; B Odra River Basin; C - Beskids Mountains). Data source: CLES. 
Tab. 1: Ecosystem services (ES) researched and applied for economic valuation, adapted from Frélichová et al. (2014)

\begin{tabular}{l|l|l}
\hline Ecosystem service category & Service/benefit & \multicolumn{1}{|c}{ Relevant ecosystems } \\
\hline & Crop & A \\
& Biomass & A, F, G, W, WET \\
& Fish & W, WET \\
Provisioning & Timber & F \\
& Non-timber & F \\
& Game & F \\
& Water & W, WET \\
\hline \multirow{5}{*}{ Regulating } & Air quality & F \\
& Climate & A, F, G, U, WET \\
& Disturbance & W, WET \\
& Erosion & A, F, G, WET \\
& Nutrient & A, G, W, WET \\
& Pest control & A, F, G, WET \\
& Pollination & A \\
& Water cycle & A, F, G, U, WET \\
& Water quality & G, F, WET \\
\hline \multirow{2}{*}{ Cultural } & Aesthetic value & A, F, W, WET \\
\hline
\end{tabular}

Explanation of acronyms: A - agricultural, F - forests, G - grasslands, U - urban, W - water, WET - wetlands

\section{Economic valuation}

Data from the EKOSERV database were used for a monetary valuation of ecosystem services in the PLAs. The database was set up by CzechGlobe in 2012-2013 as part of a project supported by the Technology Agency of the Czech Republic "Integrated assessment of ecosystem services in the Czech Republic" (EKOSERV), focused on quantification, mapping and economic valuation of ecosystem services in the Czech Republic. Outputs from this integrated application of the concept of ecosystem services were intended to support decision-making processes in the Czech Republic, e.g. by estimating the total monetary value of ecosystem services, which equals $150 \%$ of the annual Czech gross domestic product (Frélichová et al. 2014). The method for estimating the monetary values of ecosystem services used when creating the EKOSERV database was benefit transfer, often regarded as a relatively fast and least data demanding method for ecosystem service value assessment (Frélichová et al. 2014; Wilson \& Hoehn
2006). Generally, the benefit transfer makes use of available data for ecosystem service valuation and applies them in a new, similar context (Liu et al. 2010). The benefit transfer method can provide relatively appropriate indicative value estimates.

Based on a systematic (scientific) review of the literature, the benefit transfer method was applied and resulted in a database with nearly 200 monetary values for various ecosystem services. For a more detailed description of the process of the EKOSERV database creation including the valuation methods, see the full paper by Frélichová et al. (2014).

\section{Results}

\section{Total value}

The total value of ecosystem services in all 25 PLAs reached $€ 51$ billion/year. The PLA with the highest total monetary value of ecosystem services was Beskids Mountains, totalling $€ 7.3$ billion/year. Beskids Mountains are also the 
PLA with the largest surface area $\left(1,205 \mathrm{~km}^{2}\right)$, and therefore, it was expected that the area might significantly affect the total value. Another important variable is the share of the most valuable ecosystems, which is further described in a relevant subsection. On the other hand, the PLA with the lowest total monetary value of ecosystem services was Odra River Basin, amounting to $€ 102$ million/year. Similar to the previous one, Odra River Basin is the second smallest PLA with regard to the surface area $\left(80 \mathrm{~km}^{2}\right)$ and therefore, it was expected that the total value would stay on the lower end of the scale. Fig. 2 presents the total value of the ecosystem services in all the PLAs considered in this study, their spatial distribution in the Czech Republic and their classification into 5 categories regarding the total value of the ecosystem services provided in EUR per year.

\section{Value per unit area}

To facilitate the comparability between the PLAs, the monetary values were transformed and expressed as values per unit area $\left(\mathrm{km}^{2}\right)$. As a result, this step regulates the influence of PLA size on the outcome value. The PLA with the highest monetary value per unit area was Český les Mountains, totalling €6.5 million/ $\mathrm{km}^{2} /$ year. On the other hand, the lowest value per unit area was that of Odra River Basin with $€ 1.2$ million $/ \mathrm{km}^{2} /$ year, which scored the lowest total value as well. The possible reasons and implications of this are discussed in the respective subchapter. A complete list of the PLAs and the value of ecosystem services in EUR/ $\mathrm{km}^{2} /$ year is shown in Fig. 3.

\section{Exploring ecosystems with the highest value}

To further explore the composition of the total value per PLA, the following analysis is focused on decoding which ecosystems have the highest share in the value, in other words, how it relates to actual habitat/ecosystem structure of the PLA. Of a total number of 25 PLAs, three were selected for this analysis, based on the results from the previous section (total value and value per unit area). The first detailed overview is given for Beskids Mountains, which scored number one for the total monetary value of ES, possibly due to its largest surface area. Second was Odra River Basin, which scored the lowest number for the total value and, at the same time, for the value per unit area of the PLA. Third PLA for a deeper analysis is Český les Mountains, which scored highest in the value per unit area.

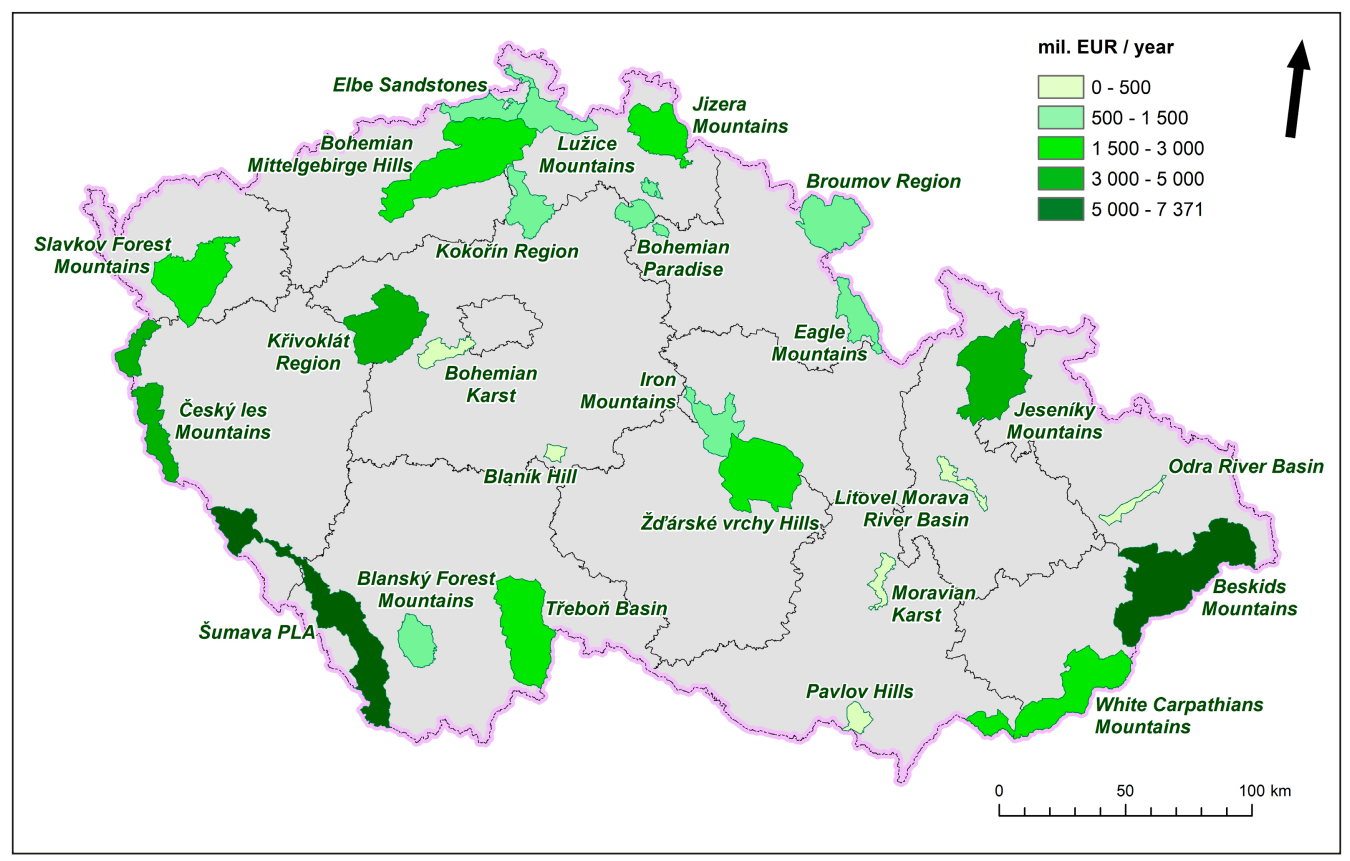

Fig. 2: Total monetary value of ES in PLAs per year. 


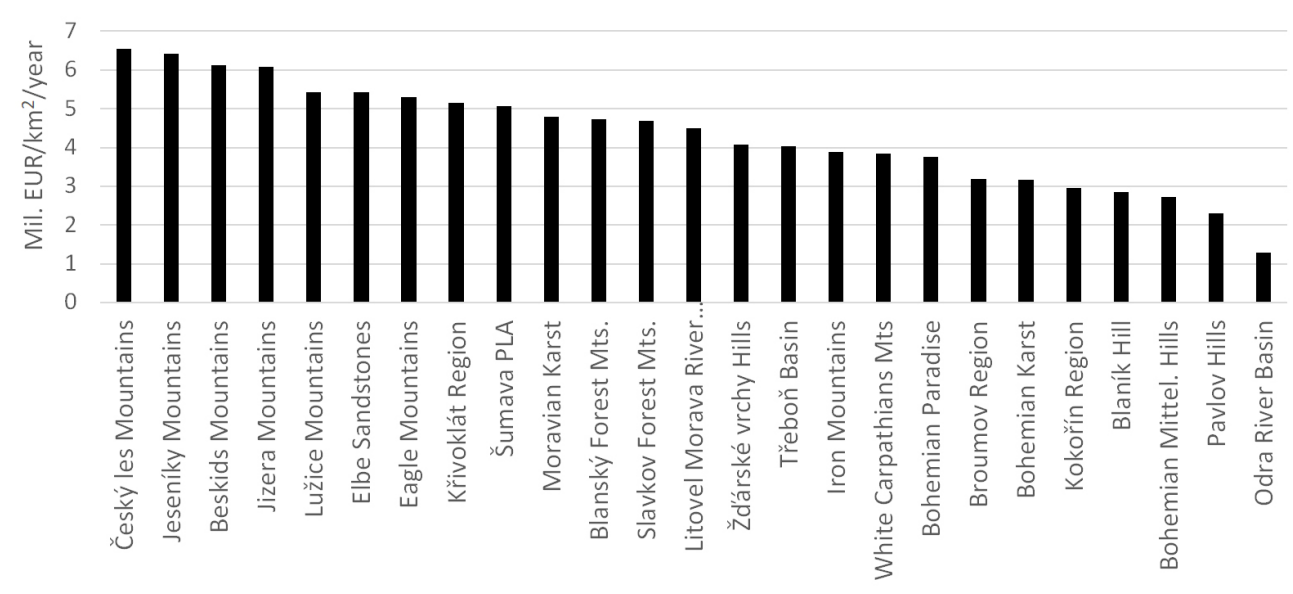

Fig. 3: Average monetary value of ES in PLAs per unit area $\left(E U R / \mathrm{km}^{2}\right)$ per year.

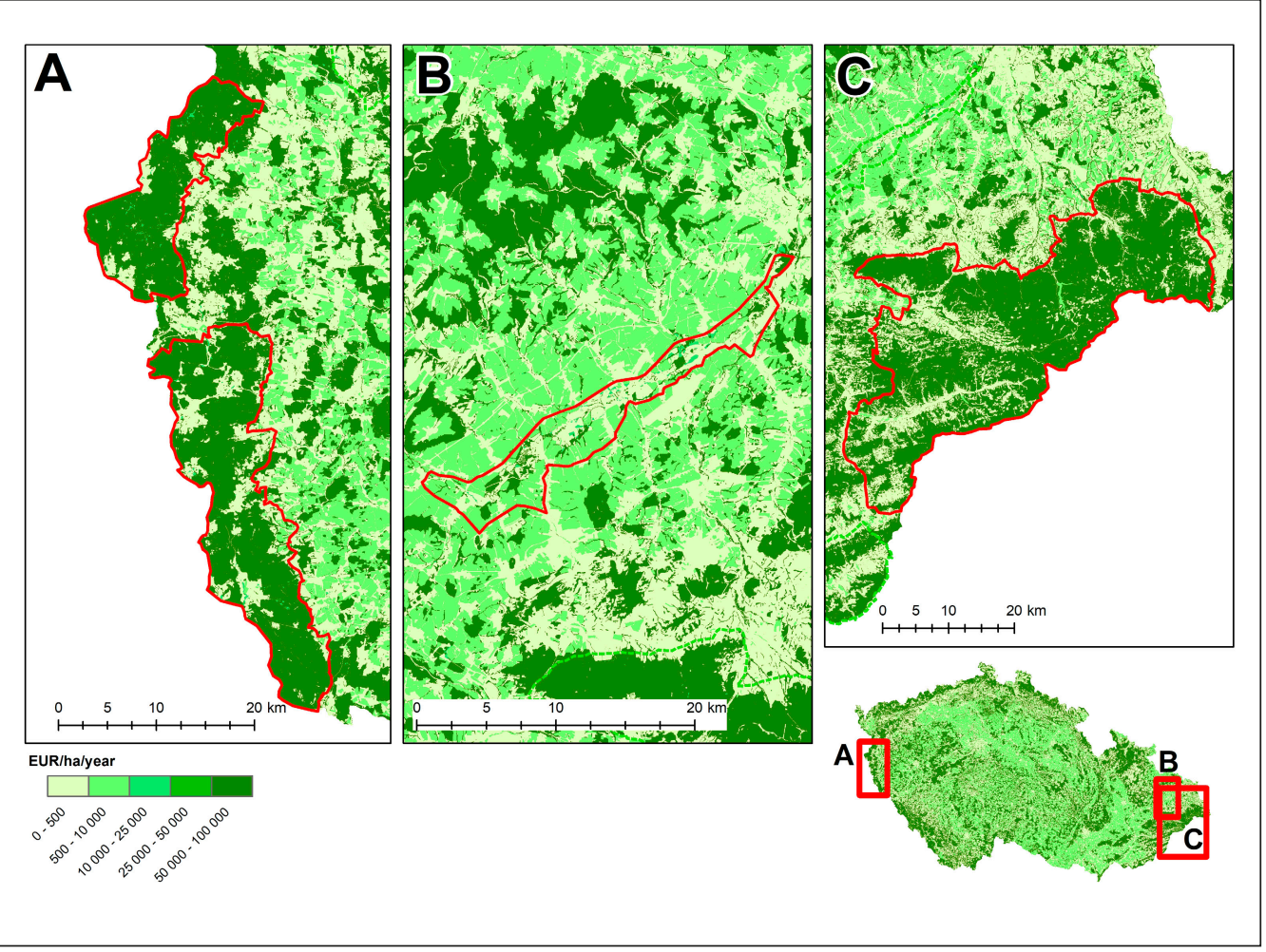

Fig. 4: Value perunit area in three selected PLAs (A - Českýles Mountains; B - Odra River Basin; C - Beskids Mountains). 
The Fig. 4 presents the three selected PLAs; the values per unit area are graphically divided into 5 categories to capture the whole gradient from very low to very high values.

\section{Beskids Mountains}

The largest PLA in the Czech Republic, Beskids Mountains, is a dominantly forested mountainous area bordering Slovakia in the western part of the Carpathian mountain range. It has a surface area of approximately $1,205 \mathrm{~km}^{2}$ and ranges from 326 to 1,319 metres above sea level (AOPK 2015).

In Beskids Mountains PLA, the value of ecosystem services from forest ecosystems covers nearly $100 \%$ of the total monetary value, possibly due to the high share (76\%) of areas with forests in the total surface area. To investigate what habitats contribute the most to the estimated economic value, the value of the forest ecosystems was broken down to the lowest level of habitat categories. From a total of 13 forest habitat types considered in the CLES, 9 of them contribute to the economic value of ecosystem services in Beskids Mountains. The highest value is brought by intensive coniferous forests (67\%), followed by beech forests (21\%), and intensive mixed forests (8\%). A full list of relevant forest habitats and their share in the total value of ecosystem services from forest ecosystems is presented in Fig. 5.

\section{Odra River Basin}

Odra River Basin is among the smallest PLAs in the Czech Republic, with approximately $80 \mathrm{~km}^{2}$ (AOPK 2015). The PLA is nested around the Odra River and its natural meanders with a number of tributaries, cut-off meanders, oxbows, periodical or temporary pools, ponds and other water bodies. It lays in a lowland landscape, ranging from 212 to 309 metres above sea level (AOPK 2015).

In Odra River Basin PLA, the value of the ecosystem services from forest ecosystems covers about $92 \%$ of the total value, compared with the share of the afforested area $-16 \%$ of the total surface area. Other considerable shares on total average value are those of agricultural ecosystems (4\%) and wetlands (3\%). Grasslands and aquatic ecosystems have both $1 \%$ and urban ecosystems almost zero.

As forest ecosystems contribute the most to the overall value, the interesting part was to unhide what particular habitats are behind those values. Seven forest habitat categories contribute to the economic value of ecosystem services in Odra River Basin. Most of the value is created by alluvial forests (70 \%), followed by oak and oak-hornbeam forests (13\%) and intensive mixed forests (9\%). A full list of relevant forest habitats and their share in the total value of ecosystem services from forest ecosystems is shown in Fig. 6.

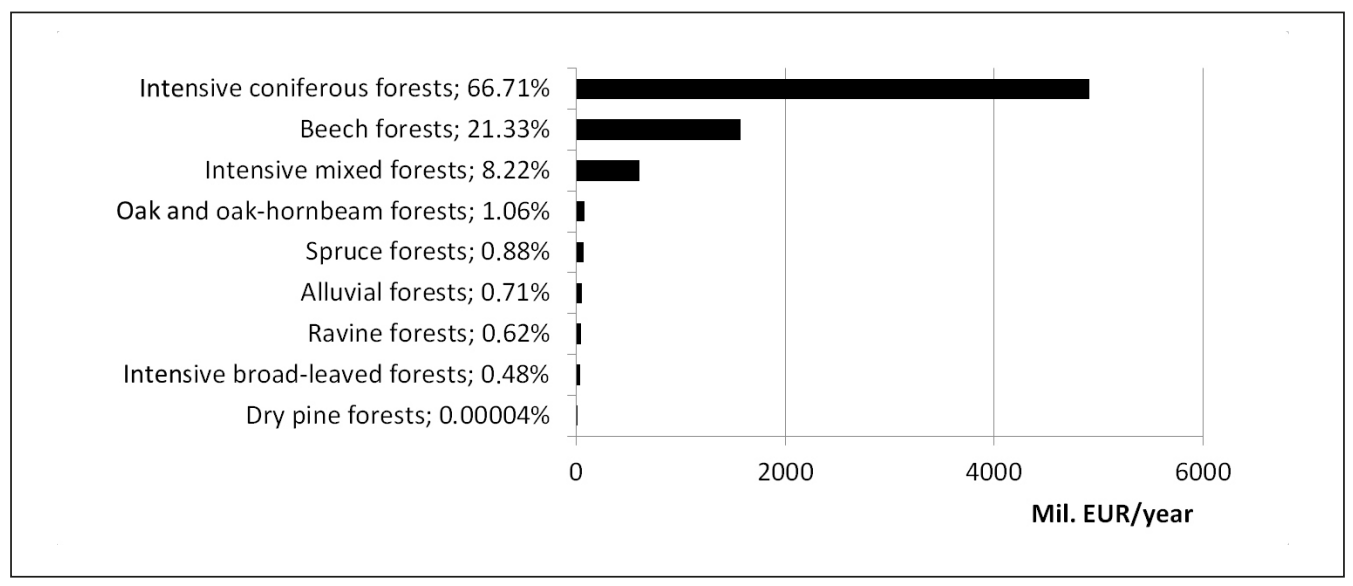

Fig. 5: Share of forest habitats on the monetary value of ES in the forests, Beskids Mountains PLA. 


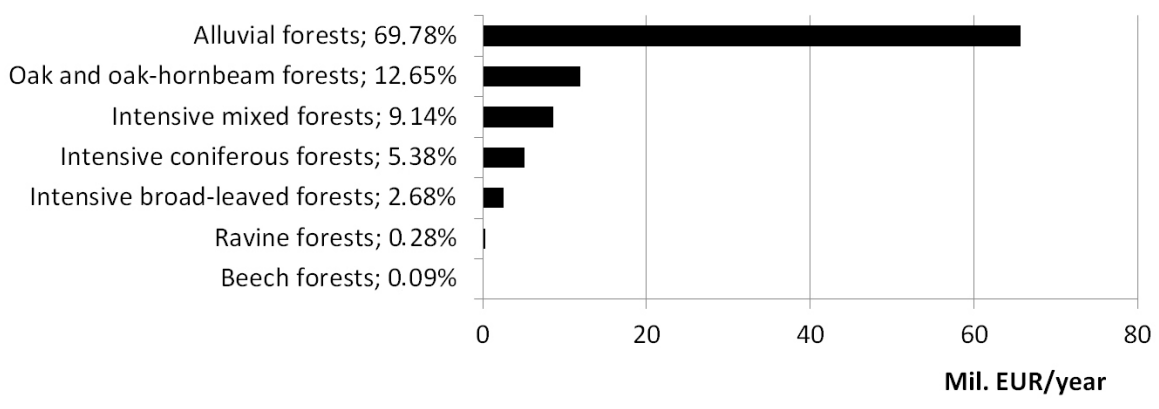

Fig. 6: Share of forest habitats on the monetary value of ES in the forests, Odra River Basin PLA.

\section{Český les Mountains}

Český les Mountains, as its name suggests ${ }^{2}$, is an extensively afforested highland and mountain landscape area bordering Germany in the western part of the Czech Republic. It has an elevation between 442 and 1,039 metres above sea level and has a surface area of approximately $466 \mathrm{~km}^{2}$ (AOPK 2015).

In Český les Mountains PLA, the value of the ecosystem services from forest ecosystems accounts for nearly $100 \%$ of the total monetary value and the share of the afforested area accounts for $80 \%$ of the total surface area. This suggests that the forest ecosystem services are dominant regarding the monetary value in this PLA. To investigate what habitats contribute the most to the total average economic value, the value of forest ecosystems was broken down to the lowest level of habitat categories. Similar to the results in Beskids Mountains, 9 forest habitat types contribute to the economic value, but the composition is slightly different. The highest value is brought by intensive coniferous forests ( $75 \%$ ), followed by beech forests ( $12 \%$ ) and intensive mixed forests (7\%). Two more habitats have a considerable share in the value alluvial forests and spruce forests, both with $3 \%$. All other forest habitats account for $1 \%$ or less. A full list of relevant forest habitats and their share in the total value of ecosystem services from forest ecosystems is presented in Fig. 7.

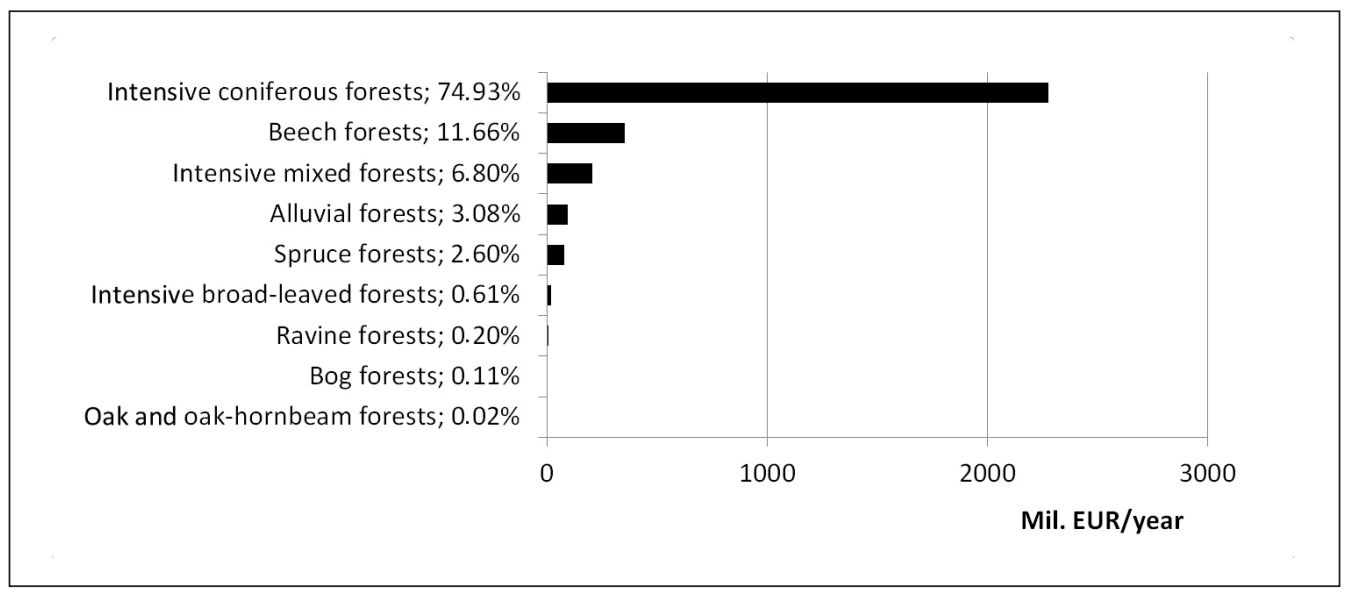

Fig. 7: Share of forest habitats in the monetary value of ES in the forests, Český les Mountains PLA.

2 "les" means forest in the Czech language. 


\section{Discussion}

Regarding the study sites covered in this study, Brdy PLA was excluded from the assessment because the data were not available due to the recent creation of this site. Therefore, the total value of ecosystem services in the PLAs would be higher if all PLAs were considered in this assessment. Concerning the figures, it is important to note the varying precision of the benefit transfer method used for the economic valuation (Eigenbrod et al. 2010; Plummer 2009; Troy \& Wilson 2006). However, the accuracy and validity of values can be refined by following certain guidelines, established by economists (Plummer 2009). Nevertheless, this method provides convenient flexibility in cases where data and time are limited resources, and a rapid ecosystem services evaluation affords us important inputs for environmental management (Jadhav et al. 2017).

The total value of ecosystem services in the PLAs was significantly influenced by the surface area, though this was not the only determinative variable. To evaluate the role of ecosystem type composition or particular habitats on a finer scale, three PLAs served as case studies. Český les Mountains as well as Beskids Mountains had nearly $100 \%$ of their total economic value generated by forest ecosystems. After the role of surface area was dismissed using the value per unit area ratio, Český les Mountains had an average value of ecosystems services totalling $€ 6.5$ million/ $\mathrm{km}^{2} /$ year (the highest score for unit area assessment), and Beskids Mountains had €6.1 million/ $\mathrm{km}^{2} /$ year (third highest score for unit area assessment). The third case study, the Odra River Basin PLA had "only" €1.2 million $/ \mathrm{km}^{2} /$ year which resulted in the lowest value in both analyses, because of its relatively small area (second smallest surface area), and a relatively small share (16\%) of forest ecosystems in its surface area. These results suggest a dominant role of forest ecosystem services in the estimated economic value.

A similar study conducted by Hein (2011) on economic benefits of protected areas in the Netherlands showed a conservative estimate of $€ 0.2$ million $/ \mathrm{km}^{2} /$ year for eight ecosystem services researched, compared with the 18 ecosystem services included in this study. A study from Central European region by Getzner (2009) estimates a mean value of $€ 3.5$ million $/ \mathrm{km}^{2} /$ year for seven ecosystem services provided by the Tatra
National Park in Poland, and $€ 1.1$ million $/ \mathrm{km}^{2} /$ year for nine ecosystem services provided by the Slovak Paradise National Park in Slovakia.

\section{Conclusion}

The total economic value of ecosystem services in the PLAs in the Czech Republic varied from $€ 102$ million/year to $€ 7.3$ billion/year and from $€ 1.2$ to $€ 6.5$ million $/ \mathrm{km}^{2} /$ year in the value per unit area assessment. Forest ecosystems create from $92 \%$ to nearly $100 \%$ of the total monetary value in the three case studies.

In the history of creating of the protected areas in the European region, arguments and justifications have varied to a great extent - from creating hunting grounds to conserving biodiversity and acknowledging the intrinsic value of nature (Jones-Walters \& Čivić 2013). Nowadays, even the PLAs are facing economic challenges, which are generally omnipresent for institutions of any type (Jones-Walters \& Čivić 2013). In order to explore possible arguments for protected areas, their monetary valuation may be a useful tool, translating the multiple benefits of ecosystems and their services for people and society into a common language. Nevertheless, an economic valuation or "putting a price on nature" should be treated with care to avoid a senseless commodification of nature (Hansjurgens et al. 2016; Schröter et al. 2014), which is certainly not the goal (Costanza et al. 2014). It should be largely considered as an informative argument and a communication tool for supporting nature protection, e.g. by establishing and maintaining protected areas. It is important to stress that a monetary valuation provides extra information in addition to the basic conservation goals: protecting biodiversity and natural habitats. This study expands the body of information on the economic benefits delivered by the protected areas. Furthermore, it can also help to identify and realize the social importance of these sites in other than conservation language. These results can be used to support policy and decision-making processes, even though it is still rather difficult to achieve outcomes positive both for human well-being and biodiversity (Pullin et al. 2013). Another example of applicability of such economic valuation might be an assessment of cost-benefit analysis for various objectives in the management of PLAs. 


\section{Acknowledgement}

This work was supported by the Ministry of Education, Youth and Sports of the Czech Republic as part of the National Sustainability Program I (NPU I), grant number LO1415. We thank P. Bašta for help with data processing in GIS.

\section{References}

AOPK 2015: Protected Landscape Areas of the Czech Republic. Nature Conservation Agency of the Czech Republic, Prague. http://www. ochranaprirody.cz/res/archive/300/036901. pdf?seek $=1465902968$

Abson, D. J., Von Wehrden, H., Baumgärtner, S., Fischer, J., Hanspach, J., Härdtle, W., HeinRICHS, H. 2014: Ecosystem services as a boundary object for sustainability. Ecological Economics, 103: 29-37.

Bateman, I.J., Mace, G.M., Fezzi, C., Atkinson, G., TURNER, K. 2011: Economic analysis for ecosystem service assessments. Environmental and Resource Economics, 48: 177-218.

Bennett, E.M., Cramer, W., Begossi, A., Cundill, G., Díaz, S., Woodward, B.N. 2015: Linking biodiversity, ecosystem services, and human well-being: Three challenges for designing research for sustainability. Current Opinion in Environmental Sustainability, 14: 76-85.

Costanza, R., De Groot, R., BraAt, L., Kubiszewski, I., Fioramonti, L., Sutton, P., Farber, S., Grasso, M. 2017: Twenty years of ecosystem services: How far have we come and how far do we still need to go? Ecosystem Services, 28: 1-16.

Costanza, R., De Groot, R., Sutton, P., Van Der Ploeg, S., Anderson, S.J., Kubiszewski, I., FarBER, S., Turner, R.K. 2014: Changes in the global value of ecosystem services. Global Environmental Change, 26(1): 152-158.

Daily, G. C., Polasky, S., Goldstein, J., Kareiva, P. M., Mooney, H. A., Pejchar, L., Ricketts, T. H., Salzman, J., Shallenberger, R. 2009: Ecosystem services in decision making: Time to deliver. Frontiers in Ecology and the Environment, 7(1): 21-28.

Durán, A. P., Casalegno, S., Marquet, P. A., GasTON, K. J. 2013: Representation of Ecosystem Services by Terrestrial Protected Areas: Chile as a Case Study. PLoS ONE, 8(12): e82643.
Eigenbrod, F., Armsworth, P.R., Anderson, B.J., Heinemeyer, A., Giluings, S., Roy, D.B., Thomas, C.D., Gaston, K.J. 2010: Error propagation associated with benefits transfer- based mapping of ecosystem services. Biological Conservation, 143: 2487-2493.

Frélichovâ, J., VačKÁR̆, D., PÁrtl, A., LouČKovÁ, B., HARMÁČKOVÁ, Z.V., LoRENCOVÁ, E. 2014: Integrated Assessment of Ecosystem Services in the Czech Republic. Ecosystem Services, 8: 110-117.

GETZNER, M. 2009: Economic and Cultural Values Related to Protected Areas - Valuation of Ecosystem Services in Tatra (PL) and Slovensky Raj (SK) National Parks. Department of Economics (Klagenfurt University) Research Report to WWF (World Wildlife Fund) International, Vienna.

Haines-Young, R., Potschin, M. 2013: Common International Classification of Ecosystem Services (CICES): Consultation on Version 4, August-December 2012. Report to the European Environment Agency. https://cices. eu/content/uploads/sites/8/2012/07/CICESV43_Revised-Final_Report_29012013.pdf

HansjuRgens, J., Kehl, C., Loft, L. 2016: The economic approach to ecosystem services and biodiversity: Policy design and institutions matter. GAIA, 25(3): 174-181.

HeIn, L. 2011: Economic Benefits Generated by Protected Areas: the Case of the Hoge Veluwe Forest, the Netherlands. Ecology and Society, 16(2):13.

Hönigovâ, I., VačKÁR̆, D., Lorencovâ, E., MeliChAR, J., GÖtZL, M., SONDEREgGer, G., OUŠKovÁ, V., Ноร̌Ек, М., Сновот, К. 2012: Survey on grassland ecosystem services. Report to the EEA - European Topic Centre on Biological Diversity. Prague: Nature Conservation Agency of the Czech Republic, p. 78.

Ingraham, M. W., Foster, S. G. 2008: The value of ecosystem services provided by the U.S. National Wildlife Refuge System in the contiguous U.S. Ecological Economics, 67: 608-618.

Jadhav, A., Anderson, S., Dyer, M.J.B., Sutton, P.C. 2017: Revisiting ecosystem services: Assessment and valuation as starting points for environmental politics. Sustainability, 9(10): 1755.

Jones-WALters, L., ČIVIć, K. 2013: European protected areas: Past, present and future. Journal for Nature Conservation, 21(2): 122-124. 
Kull, Ch.A., De Sartre, X. A., Castro-Larrañaga, M. 2015: The political ecology of ecosystem services. Geoforum, 61: 122-134.

Liu, S., Costanza, R., Troy, A., D’agostino, J.D., Mates, W. 2010: Valuing New Jersey's ecosystem services and natural capital: a spatially explicit benefit transfer approach. Environmental Management, 45: 1271-1285.

LYYTIMÄKI, J. 2015: Ecosystem disservices: Embrace the catchword. Ecosystem Services, 12: 136.

MA (Millennium Ecosystem Assessment) 2005: Ecosystems and Human Well-Being: A Framework for Assessment. Report of the Conceptual Framework Working Group of the Millennium Ecosystem Assessment. Island Press, Washington, DC.

MAES (Mapping and Assessment of Ecosystems and their Services) 2016: Mapping and assessing the condition of Europe's ecosystems: Progress and challenges. $3^{\text {rd }}$ Report - Final, March 2016. http://ec.europa.eu/environment/ nature/knowledge/ecosystem_assessment/ pdf/3rdMAESReport_Condition.pdf

Mccauley, D.J. 2006: Selling out on nature. $\mathrm{Na}$ ture, 443: 27-28.

Plummer, M.L. 2009: Assessing benefit transfer for the valuation of ecosystem services. Frontiers in Ecology and the Environment, 7(1): 38-45.

Pullin, A.S., Bangran, M., Dalrymple, S., Dickson, K., Haddaway, N.R., Healey, J.R., Hauari, H., Hockley, N., Jones, J.P.G., Knight, T., Vigurs, C., Oliver, S. 2013: Human well-being impacts of terrestrial protected areas. Environmental Evidence, 2: 19.

Rinne, J., Primmer, E. 2016: A Case Study of Ecosystem Services in Urban Planning in Finland: Benefits, Rights and Responsibilities. Journal of Environmental Policy and Planning,18(3): 286-305.

Schröter, M., Van Der Zanden, E.H., Van Oudenhoven, A.P.E., Remme, R.P., Serna-Chavez, H.M., De Groot, R.S., Opdam, P. 2014: Ecosystem Services as a Contested Concept: A Synthesis of Critique and Counter-Arguments. Conservation Letters, 7(6): 514-523.

Schröter, M., Albert, Ch., Marques, A., Tobon, W., Lavorel, S., Maes, J., Brown, C., Klotz, S., BonN, A. 2016: National Ecosystem Assessments in Europe: A Review, BioScience, 66(10): 813-828.Steffen, W., Persson, Å., Deutsch, L., Zelasiewicz, J., Williams, M., Richardson, K., Crumley, C., Crutzen, P., Folke, C., Gordon, L., Molina, M., Ramanathan, V., Rockström, J., Scheffer, M., Schellnhuber, H.J., Svedin,
U. 2011: The anthropocene: From global change to planetary stewardship. Ambio, 40(7): 739-761.

TeEb (The Economics of Ecosystems and Biodiversity) 2013: Guidance Manual for TEEB Country Studies. Version 1. 0. http://www.teebweb.org/media/2013/10/TEEB_GuidanceManual_2013_1.0.pdf

Troy, A., Wilson, M.A. 2006: Mapping ecosystem services: Practical challenges and opportunities in linking GIS and value transfer. Ecological Economics, 60: 435-449.

Wilson, M.A., Hoenn, J.P. 2006: Valuing environmental goods and services using benefit transfer: the state-of-the art and science. Ecological Economics, 60: 335-342.

Whitham, C. E. L., Shi, K., Riordan, P. 2015: Ecosystem Service Valuation Assessments for Protected Area Management: A Case Study Comparing Methods Using Different Land Cover Classification and Valuation Approaches. PLoS ONE, 10(6): e0129748. 


\section{Supplementary material}

Tab. 1: Hierarchical classification of the Consolidated Layer of Ecosystems of the Czech Republic.

\begin{tabular}{|c|c|c|c|}
\hline Level 1 & Level 2 & Level 3 & Level 4 \\
\hline \multirow{8}{*}{$\begin{array}{l}\text { Urban } \\
\text { areas }\end{array}$} & Continuous urban fabric & Continuous urban fabric & Continuous urban fabric \\
\hline & Discontinuous urban fabric & Discontinuous urban fabric & Discontinuous urban fabric \\
\hline & $\begin{array}{l}\text { Industrial and commercial } \\
\text { units }\end{array}$ & $\begin{array}{l}\text { Industrial and commercial } \\
\text { units }\end{array}$ & $\begin{array}{l}\text { Industrial and commercial } \\
\text { units }\end{array}$ \\
\hline & Transport units & Transport units & Transport units \\
\hline & $\begin{array}{l}\text { Dump and construction } \\
\text { units }\end{array}$ & $\begin{array}{l}\text { Dump and construction } \\
\text { units }\end{array}$ & $\begin{array}{l}\text { Dump and construction } \\
\text { units }\end{array}$ \\
\hline & Green urban areas & Natural urban green areas & Urban nature \\
\hline & & Artificial urban green areas & Parks, gardens, cemeteries \\
\hline & & & Recreation and sport areas \\
\hline \multirow{5}{*}{$\begin{array}{l}\text { Agricultu- } \\
\text { ralland }\end{array}$} & Arable land & Arable land & Arable land \\
\hline & Permanent cultures & Orchards and gardens & Orchards and gardens \\
\hline & & Hop fields & Hop fields \\
\hline & & Vineyards & Vineyards \\
\hline & Permanent grasslands & Intensive grasslands & Intensive grasslands \\
\hline \multirow[t]{5}{*}{ Grasslands } & Natural grasslands & Natural meadows & Alluvial meadows \\
\hline & & & Dry grasslands \\
\hline & & & Mesic meadows \\
\hline & & & Alpine grasslands \\
\hline & & & Heaths \\
\hline \multirow[t]{14}{*}{ Forests } & Forested areas & Intensive forests & Intensive mixed forests \\
\hline & & & $\begin{array}{l}\text { Intensive broad-leaved } \\
\text { forests }\end{array}$ \\
\hline & & & Intensive coniferous forests \\
\hline & & Natural forests & Alluvial forests \\
\hline & & & $\begin{array}{l}\text { Oak and oak-hornbeam } \\
\text { forests }\end{array}$ \\
\hline & & & Ravine forests \\
\hline & & & Beech forests \\
\hline & & & Dry pine forests \\
\hline & & & Spruce forests \\
\hline & & & Bog forests \\
\hline & Scrub & $\begin{array}{l}\text { Areas with no forest cover } \\
\text { naturally }\end{array}$ & Natural Pinus mиgo scrub \\
\hline & & & Natural shrub vegetation \\
\hline & & $\begin{array}{l}\text { Areas with introduced no } \\
\text { forest cover }\end{array}$ & Introduced Pinus mugo scrub \\
\hline & & & $\begin{array}{l}\text { Introduced shrub } \\
\text { vegetation }\end{array}$ \\
\hline
\end{tabular}




\begin{tabular}{|c|c|c|c|}
\hline Level 1 & Level 2 & Level 3 & Level 4 \\
\hline \multirow[t]{3}{*}{ Wetlands } & Wetlands & Natural wetlands & $\begin{array}{l}\text { Wetlands and litoral } \\
\text { vegetation }\end{array}$ \\
\hline & & Natural peatbogs & Peatbogs and springs \\
\hline & & Anthropogenic swamps & Swamps \\
\hline \multirow{4}{*}{$\begin{array}{l}\text { Aquatic } \\
\text { ecosystems }\end{array}$} & Water bodies & Natural water bodies & Lakes \\
\hline & & $\begin{array}{l}\text { Anthropogenic water } \\
\text { bodies }\end{array}$ & Ponds \\
\hline & Water courses & Natural water courses & Natural water courses \\
\hline & & $\begin{array}{l}\text { Anthropogenically } \\
\text { influenced water courses }\end{array}$ & $\begin{array}{l}\text { Anthropogenically } \\
\text { influenced water courses }\end{array}$ \\
\hline \multirow[t]{2}{*}{ Bare land } & Bare rock & Artificial rocks & Quarries and mining sites \\
\hline & & Natural rocks & Rocks and stones \\
\hline
\end{tabular}

